\title{
Framework of "No-Show Phenomenon" for Admission Offers to Higher Institutions among Students
}

\author{
Mohd Effendi Ewan Mohd Matore ${ }^{1 *}$, Nordin Abd Razak ${ }^{2}$ \\ ${ }^{1}$ Centre of Educational Planning and Policy, Faculty of Education, Universiti Kebangsaan Malaysia, Bangi, Malaysia \\ ${ }^{2}$ School of Educational Studies, Universiti Sains Malaysia, Penang, Malaysia \\ Email: *effendi@ukm.edu.my,norazak@usm.my
}

How to cite this paper: Matore, M. E. E. M., \& Razak, N. A. (2019). Framework of "No-Show Phenomenon" for Admission Offers to Higher Institutions among Students. Creative Education, 10, 2804-2814. https://doi.org/10.4236/ce.2019.1012207

Received: October 21, 2019

Accepted: November 25, 2019

Published: November 28, 2019

Copyright () 2019 by author(s) and Scientific Research Publishing Inc. This work is licensed under the Creative Commons Attribution International License (CC BY 4.0).

http://creativecommons.org/licenses/by/4.0/

\section{c) (i) Open Access}

\begin{abstract}
Every year there are many students who get admission to higher education institutions. However, there are many factors that influence the choice of students to higher education. These factors can be explained through several models or theories. This paper aims to discuss the theories that explain the "No-Show Phenomenon". The theory chosen is the Choice Theory and is supported by several models that can be used namely Economic Model, Social Model and Combined Model. This model is supported by the applications of Push and Pull Theory. This study contributes to the extent to which this "No-Show Phenomenon" framework model to explain the factors influencing the failure of the candidate to study at the first degree of enrollment as a Higher Educational Institutions student, despite being offered a place of study at the university after going through several test and qualification processes to determine the merits and qualifications of the student.
\end{abstract}

\section{Keywords}

No-Show Phenomenon, Admission, Higher Institutions, Framework

\section{Introduction}

Excellent student generally has many types of intelligence. Previous studies showing associations between intelligence have been made in the local context (Mohd Effendi Ewan, 2019a, 2019b; Mohd Effendi Ewan \& Ahmad Zamri, 2016). This intelligence helps students overcome the challenges of life has been exposed in previous studies in the context of higher education (Ahmad Zamri \& Mohd Effendi Ewan, 2017; Mohd Effendi Ewan et al., 2017). Other than this type of intel- 
ligence, students also need the intelligence to make choices in life. One of the important decisions that vital for them is a decision to pursue their study to higher educational institutions. The students' decisions about pursuing study in higher education are based on a number of issues.

Firstly, students who finish high school need to decide whether to pursue higher education. Secondly, students who choose to pursue their studies must make choices about programs or areas of higher education and institutions. There are also choices and criteria that influence the choice of students of institutions of higher learning. Some models or theories try to explain the factors that influence students' choice to study at a higher education institution.

This study aims to focus on issues related to the failure of candidates to pursue their first degree at the Institution of Higher Learning (IPT) and to enroll as students despite being offered a place at the HEIs after undergoing various testing and qualification processes to determine merit and eligibility the student. Therefore, the question is what factors are causing these students to not register at the HEIs even though they have been offered a place based on their application to the HEIs. What are the factors that cause them to stay or leave university? This paper aims to discuss the theories that explain the "No-Show Phenomenon". The theory chosen is the Choice Theory and is supported by several models used in this study namely Economic Model, Social Model and Combined Model. This model is supported by the use of Push and Pull Theory.

\section{Choice Theory}

There are many theories categorized under cognitive theories such as Cognitive Theory of Behavior, Emotional Reasoning Theory of Behavior, Reality Therapy Theory and others. One of the theories that can explain how a person makes choices is Choice Theory introduced by William Glasser (1998). This theory explains that although a human being generally shares the same needs, the behavior of an individual in meeting the needs they are different. From the very beginning of life or birth, each person has his or her own life that can be either fun or sad. With it, we begin to know how to meet our needs. Because of each person's experience is different, they will apply different ideas and learn them differently to meet their needs.

This theory discusses how an individual behaves and why they behave based on a number of perspectives such as psychology of internal and external control, world of quality, basic needs, sense of world, real world, values, knowledge, scale of consideration, overall behavior, system of behavior, a successful and failed identity. Choice Theory as show in Figure 1 explains that we choose to act the way we want, including sadness. Individuals are free to act on the basis of internal motivation, our own choice, flexibility, goals and creativity (Glasser, 2000). This theory explains that an individual is responsible for making decisions in his or her life. Each choice is made based on their basic needs and at their own risk. An individual is able to choose effective and ineffective behaviors where effective 


\section{CHOICE THEORY- WHY AND HOW WE BEHAVE}

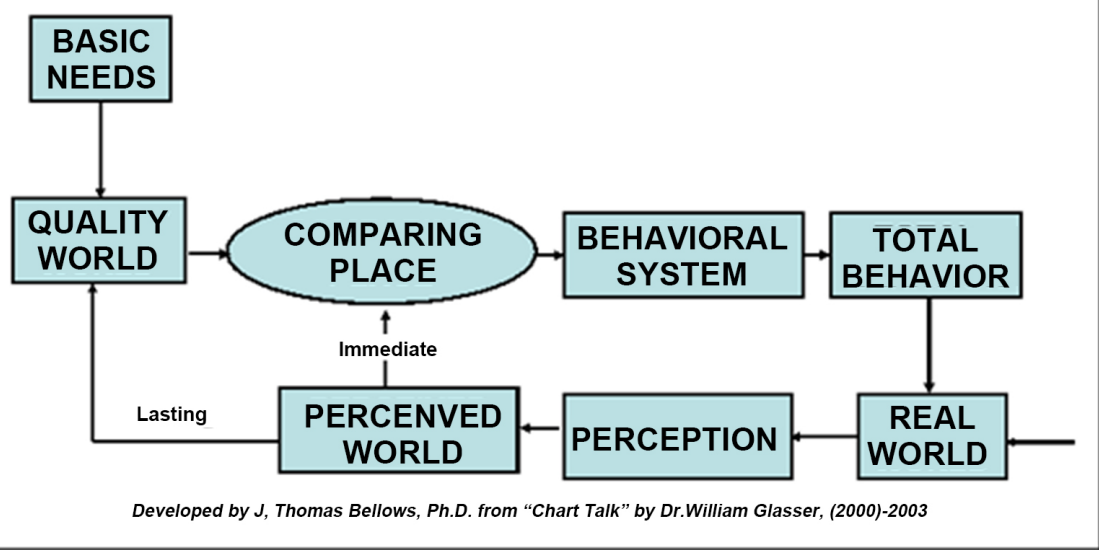

Figure 1. Choice theory-why and how we behave.

behavior builds on successful identities and ineffective behavior builds on failed identities.

Glasser (2000) sees human problems as a result of unmet basic needs. Basic needs include five basic needs that are 1) to love and to be loved; 2) to gain power and keep respect; 3) fun; 4) desire for freedom and 5) to survive and be secured. According to Glasser (1986) psychological desire includes an individual who loves and wants to be loved by others, wants honor from others, wants freedom and wants happiness. This loving and caring aspect includes the needs of love, intimacy, sense of belonging to family, friends, employers and others. The desire to reward includes the need for achievement, skill, efficiency, influence. Choice Theory also emphasizes the nature of individual responsibility. Glasser (1965) defines responsibility as the ability to meet a need, and willing to face obstacles to meet the needs. Glasser (1998) also rejects the concept of dreams without relying on reality.

Quality World mean that individuals have their own dreams. It depends on the experience with others, the things, the beliefs, and the situations we are experiencing. The quality requirements will also produce the desired and the desired. Overall Behavior (Total Behavior) refers to the overall behavior, thoughts, feelings, and physiology of the behavior. It can control one's own actions and thoughts but is difficult to control. Successful identity means one who is loved, cherished and able to meet his psychological needs while one who fails to mean one who is not loved, unbalanced personality, lack of confidence and despair. In conclusion, an individual can control their own behavior. We can get something from someone but not necessarily what we want. Most psychological problems are caused by relationship problems and this problem is an ongoing process in human life. We need to worry about the future compared to the past. A human being has the basic needs of wanting to love and to own, to want to honor, to 
want freedom, to want happiness and to want to live. We will be satisfied after choosing to fulfill all our wishes. In the event of a conflict between self-will, it affects behavior, thinking, feeling and physiology.

\section{Selection Models to the IPT}

The model choices for institutions of higher learning is as follows: a) Economics model; b) Sociology models and c) Combined models.

\subsection{Economics Model}

The economic model for human capital development emphasizes rational decision-making when studying student selection. Individuals are expected to act rationally in ways that maximize their utility, through their own personal choices. Students choose institutions based on the level and value that each institution offers through cost comparisons with perceived benefits. The assumption of an economic model is that students will choose a particular institution when the advantages gained by enrolling in that institution are greater than the benefits they receive when enrolling in another institution.

Some recent studies have focused on the effects of financial factors such as family income, low tuition, scholarships and financial aid (Azarcon, Gallardo, Anacin, \& Velasco, 2014; Kitsawad, 2013; Koe \& Siti Noraisah Filaring, 2012; Kusumawati, 2013; Mehboob, Shah, \& Bhutto, 2012; Ojo \& Raja Nerina Raja Yusofu, 2013). However, Paulsen (2001) states that students' perceptions of economic benefits and higher education costs are different because financial factors are less significant. These include differences in expectations of benefits and costs that may be based on differences in access to college information or differences in contextual aspects, including factors related to family, school, or community, higher educational contexts, and/or social, economic, and basic contexts.

\subsection{Sociology Model}

The sociological model is different from the economic model. The economic model assumes that students rationally decide which higher education institution offers the highest value. The sociological model describes the process that considers the elements of decision making that develop throughout a student's life. The sociological approach to college choice often emphasizes the ways in which socio-economic characteristics influence student decisions. According to sociological approaches, student behavior variables (e.g., academic performance); interact with background variables (for example, parental social status) to determine student educational aspirations.

The sociological model has evolved from the Traditional Status Model of Achievement developed in the 1980s (Hearn, 1984; Sewell, Hauser, \& Wolf, 1986). This Model of Traditional Sociological Status Achievement usually focuses on the impact of students' socio-economic status on their educational aspirations. 
The model suggests that educational aspirations are determined by academic achievement and achievement and socio-economic status (Hossler, Schmit, \& Vesper, 1999). Recent research focuses on the ways in which sociological constructs in cultural and social development affect students' choice of college. Like human capital, cultural and social capital also increases productivity. Cultural capital refers to a system of attributes such as language skills, cultural knowledge, and decency, derived partly from parents and which determine an individual's class status (Bourdieu, 1986). Simple and upper-class individuals have the most important form of cultural capital (McDonough, 1997).

Individuals who do not have the cultural capital needed may underestimate their educational aspirations because they do not know certain cultural norms. Social capital is closely linked to cultural capital and focuses on social networks and the ways in which it is maintained. Coleman (1988) suggested that parents play a major role in promoting their children's social capital while Bourdieu (1986) argues that social capital comes from social networks.

Sociological approaches are useful in understanding the ways in which structural constraints and opportunities shape individuals' perspectives and orientations toward college choices. Sociological approaches are also useful for exploring the differences between college and group choices. Bourdieu (1986) argues that barriers are based on race/ethnicity, class, and gender that impede access to institutional resources. Individual systems such as thoughts, beliefs, perceptions, as well as the types of cultural and social capital they possess, partly reflect an individual's race/ethnicity, class, and gender (Horvat, 2001). The sociological approach also does not offer a framework for studying how individuals ultimately decide whether to pursue higher education, apply for colleges, or enroll in specific colleges or universities (Manski \& Wise, 1983).

\subsection{Combined Model}

The Combined Model includes the most important indicators or indicators of the Economic Model and the Sociological Model in the decision-making process (Joseph \& Joseph, 1998, 2000). This model allows for a great deal of analytical power, a combination of sociological perspectives and rational decision-making. The discussion will involve three types of combined models: a) Jackson Model; b) Chapman's model; and c) Hanson and Litten models.

\subsubsection{Jackson Model (1982)}

This model proposes that students' choice of college includes three levels of priority, exclusion and evaluation.

a) Priority Level

Jackson explained that priorities include student aspirations and views of college enrollment, which are shaped by the student's academic achievement, family background and social context (for example, peer influence, neighborhood, and school).

b) Exemption Level 
In the second stage of this exclusion phase, students will go through the process of removing some institutions from the potential list. Tuition fees, location, and academic quality are among the factors to be considered in eliminating higher education institutions.

c) Evaluation Level

In the final stage of the evaluation phase, students are faced with a set of institutional choices; they make their final choice using a rating scheme.

\subsubsection{Chapman (1981) Model}

This model emphasizes that college choice by students is influenced by a set of student characteristics in combination with a series of influences-external influences. External influences can be classified into three categories: a) significant individual influence; b) the permanent features of the institution; and c) the institution's own efforts to communicate with prospective students. Both student characteristics and external influences contribute to the formation of general expectations of college life.

\subsubsection{Hanson (1989) Dan Litten Model}

This model explains that college selection is an ongoing process. The process consists of five steps: a) college aspirations; b) initiate the search process; c) collecting information; d) submit an application; and finally, e) sign up. Hanson and Litten identified a set of variables that influence college choice processes, including:

a) Background features (for example, parental income, education, gender);

b) Personal characteristics (e.g., academic ability, class rank, and self-image);

c) High school characteristics (e.g., social composition, programs, and curriculum);

d) College features (e.g., cost, size, program, timeliness in answering questions).

They also introduced public policies, such as financial support, as intermediary variables. The Hanson and Litten models are a mix between the student-based model Jackson and the more institutional-based model Chapman.

\section{Push and Pull Model}

The push and pull theory in this study is used as a theoretical framework in determining the factors that influence a student's choice of educational institution to pursue further studies. Dissociation factors mean internal motives that influence students to study at an institution while factors of attraction explain external motives that determine that student's choice. A study by Mazzarol \& Soutar (2002) concluded that push factors mean that a country's resources are the driving factor in students' decision to study abroad, while pull factors mean that factors in the host country attract foreign students to a particular country.

McMahon (1992) conducted a preliminary study of the factors that influence international students in decision making. He proposes two models to describe the flow of international students from 18 developing countries to the United 
States in the 1960s and 1970s. The first model involves push factors from a country's resources, including higher education and economic strength of each country. The second model focuses on economic, political, and social factors as a pull factor for the United States as a destination for higher education.

Almost all research on international student motivation and decision-making has been conducted since McMahon adopted the "push-pull" framework. One of the most cited studies is Mazarrol \& Soutar (2002). They studied the motivations of 2485 students who had traveled from four different Asian countries to Australia to pursue postgraduate studies. Mazzarol and Soutar (2002) conclude that push factors function in a resource-rich country to initiate students' decision to study abroad, while pull factors operate in a host country to attract students to a particular country compared to other countries.

Factors commonly cited in the literature are lack of capacity and opportunities in the home country of the student, lower quality of education, employer preference for overseas education, lack of specific subjects, and political and economic problems in the home country. The most frequently cited factors in the literature include the quality of education and reputation of the country or institution, high ranking, better job opportunities, opportunities to improve English language skills and opportunities for different cultural experiences. Personal and humanitarian factors are also important in determining student choices, such as individual attitudes to religion and safety, and the influence of suggestions from family, friends, teachers and agents. Students are increasingly being influenced by networks and users of social sites, such as Rate MyProfessors.com (Wilkins \& Epps, 2011). Although the push-pull model is most commonly used for students choosing to study in Western countries such as Australia, the United Kingdom and the United States, studies have found that the trend is also emerging recently in other countries, particularly in Asia (for example Li \& Bray, 2007; Padlee, Kamaruddin, \& Baharun, 2010). The push-pull model was originally developed to explain the factors that influence human movements for migration (Lee, 1966) but it has become the most commonly used tool by educational researchers to assist in the examination and description of international student selection patterns for a given institution. This model has been used to understand international student flows, decisions or motivations for study abroad and international student choice for a country and institution (Chen, 2007a). Although the basic model of push and pull for an international student's selection mechanism is useful as an explanatory mechanism, it has limitations (Li \& Bray, 2007). Figure 2 illustrated the "No-Show Phenomenon" framework that included three models that involved the "No-Show Phenomenon" emphasizing on factors that influence the choice of students to higher education.

Both push and pull factors are external motivators that influence student behavior and their choices, but the individual's choice and personal characteristics of the student are largely undisclosed. Individual learners may respond to different impulses and factors of interest in different ways. Various researchers have developed a more sophisticated conceptual model of international student 


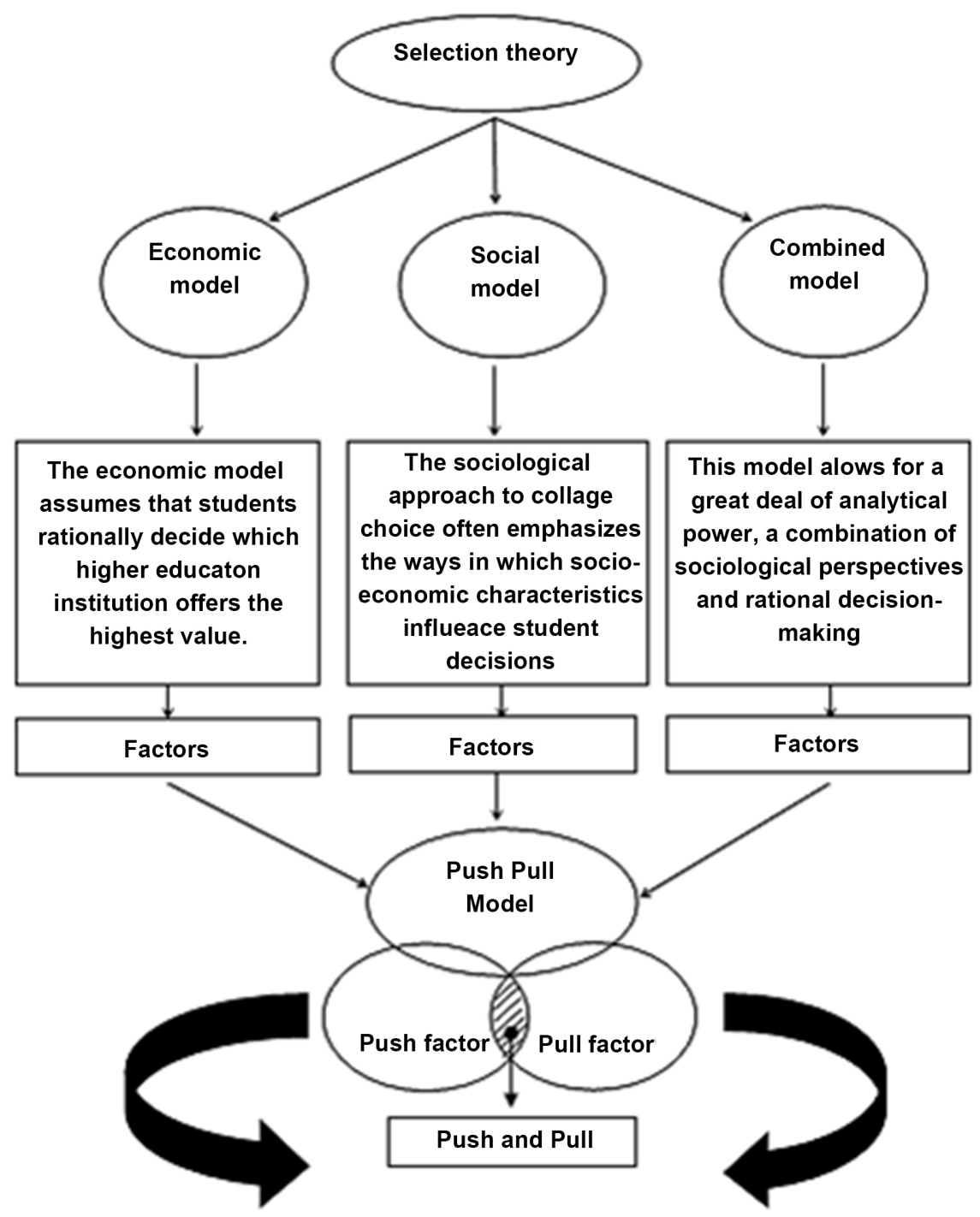

Figure 2. "No-Show Phenomenon" framework.

choice based on the push and pull model. For example, a study by Cubillo, Sánchez, \& Cerviño (2006) considers personal reasons, city and country image, institutional image and program evaluation. Chen's (2007b) model also includes student characteristics such as socio-economic background, personal criteria and academic ability. Other significant factors include family, teachers and employers.

\section{Conclusion}

This study will determine to what extent this model is able to explain the factors influencing the failure of the candidate to study at the first degree of enrollment as a higher education university student despite being offered a place in university after going through several test and qualification processes to determine the merits and eligibility of the student. The limitations on this study can be improved by categorizing the dominant reasons from the students' perspectives. 
The models selected needs to be tested in our local context. Future research can be done with focusing on the different setting of institutions and cultural context. Or else, the researcher also can investigate the diversity of reasons with qualitative approach and in depth interviews. In a nutshell, this "No-Show Phenomenon" framework will benefit future researchers to produce empirical research in a larger scale.

\section{Funding}

This research was supported by the Universiti Kebangsaan Malaysia under grant of UKM PP-FPEND-2019.

\section{Conflicts of Interest}

The authors declare no conflicts of interest regarding the publication of this paper.

\section{References}

Ahmad Zamri, K., \& Mohd Effendi Ewan, M. M. (2017). Assessing Challenges among University Undergraduates: A Case of University Sains Malaysia. Advanced Science Letters, 23, 2894-2897. https://doi.org/10.1166/asl.2017.7597

Azarcon, D. E., Gallardo, C. D., Anacin, C. G., \& Velasco, E. (2014). Attrition and Retention in Higher Education Institution: A Conjoint Analysis of Consumer Behavior in Higher Education. Asia Pacific Journal of Education, Arts and Sciences, 1, 107-118.

Bourdieu, P. (1986). The Forms of Capital. In J. G. Richardson (Ed.), Handbook of Theory and Research for the Sociology of Education (pp. 241-258). New York: Greenwood Press.

Chapman, D. W. (1981). A Model of Student College Choice. Journal of Higher Education, 52, 490-505. https://doi.org/10.1080/00221546.1981.11778120

Chen, L. H. (2007a). East-Asian Students' Choice of Canadian Graduate Schools. International Journal of Educational Advancement, 7, 271-306. https://doi.org/10.1057/palgrave.ijea.2150071

Chen, L. H. (2007b). Choosing Canadian Graduate Schools from Afar: East Asian Students' Perceptions. Higher Education, 54, 759-780. https://doi.org/10.1007/s10734-006-9022-8

Coleman, J. S. (1988). Social Capital in the Creation of Human Capital. American Journal of Sociology, 94, 95-120. https://doi.org/10.1086/228943

Cubillo, J. M., Sánchez, J., \& Cerviño, J. (2006). International Students’ Decision-Making Process. International Journal of Educational Management, 20, 101-115. https://doi.org/10.1108/09513540610646091

Glasser, W. (1965). Reality Therapy: A New Approach to Psychiatry. New York: Harper \& Row.

Glasser, W. (1986). Control Theory in the Classroom. New York: Harper \& Row.

Glasser, W. (1998). Choice Theory: A New Psychology of Personal Freedom. New York: Harper Perennial.

Glasser, W. (2000). Reality Therapy in Action. New York: HarperCollins.

Hanson, K., \& Litten, L. (1989). Mapping the Road to Academia: A Review of Research 
on Women, Men and College Selection Process. In P. Perun (Ed.), The Undergraduate Woman: Issues in Education (pp. 73-98). Lexington, KY: Lexington Books.

Hearn, J. C. (1984). The Relative Roles of Academic, Ascribed and Socioeconomic Characteristics in College Destinations. Sociology of Education, 57, 22-30. https://doi.org/10.2307/2112465

Horvat, E. M. (2001). Understanding Equity and Access in Higher Education: The Potential Contribution of Pierre Bourdieu. In J. C. Smart (Ed.), Higher Education: Handbook of Theory and Research (Vol. 16, pp. 158-171). New York: Agathon Press.

Hossler, D., Schmit, J., \& Vesper, N. (1999). Going to College: How Social, Economic and Educational Factors Influence the Decisions Students Make. Baltimore, MD: John Hopkins University Press.

Joseph, M., \& Joseph, B. (1998). Identifying Needs of Potential Students in Tertiary Education for Strategy Development. Quality Assurance in Education, 6, 90-96. https://doi.org/10.1108/09684889810205741

Joseph, M., \& Joseph, B. (2000). Indonesian Students' Perceptions of Choice Criteria in the Selection of a Tertiary Institution: Strategic Implications. International Journal of Educational Management, 14, 40-44. https://doi.org/10.1108/09513540010310396

Kitsawad, K. (2013). An Investigation of Factors Affecting High School Student's Choice of University in Thailand. Doctoral Thesis, Wollongong: University of Wollongong.

Koe, W.-L., \& Saring, S. N. (2012). Factors Influencing the Foreign Undergraduates' Intention to Study at Graduate School of a Public University. Jurnal Kemanusiaan, 19, $57-68$.

Kusumawati, A. (2013). A Qualitative Study of the Factors Influencing Student Choice: The Case of Public University in Indonesia. Journal of Basic and Applied Scientific Research, 3, 314-327.

Lee, E. S. (1966). A Theory of Migration. Demography, 3, 47-57. https://doi.org/10.2307/2060063

Li, M., \& Bray, M. (2007). Cross-Border Flows of Students for Higher Education: PushPull Factors and Motivations of Mainland Chinese Students in Hong Kong and Macau. Higher Education, 53, 791-818. https://doi.org/10.1007/s10734-005-5423-3

Manski, C. F., \& Wise, D. (1983). College Choice in America. Cambridge, MA: Harvard University Press. https://doi.org/10.4159/harvard.9780674422285

Mazzarol, T., \& Soutar, G. N. (2002). Push-Pull Factors Influencing International Student Destination Choice. International Journal of Educational Management, 16, 82-90. https://doi.org/10.1108/09513540210418403

McDonough, P. M. (1997). Choosing Colleges: How Social Class and Schools Structure Opportunity. Albany, NY: State University of New York Press.

McMahon, M. E. (1992). Higher Education in a World Market: An Historical Look at the Global Context of International Study. Higher Education, 24, 465-482. https://doi.org/10.1007/BF00137243

Mehboob, F., Shah, S. M. M., \& Bhutto, N. A. (2012). Factors Influencing Student's Enrollment Decisions in Selection of Higher Education Institutions (HEI'S). Interdisciplinary Journal of Contemporary Research in Business, 4, 558-568.

Mohd Effendi Ewan, M. M. (2019a). Structural Equation Model (SEM) in Assimilating EQ, SQ and AQ for Mechanical Students' Context. In Proceedings of the Mechanical Engineering Research Day (pp. 230-231). Melaka: Universiti Teknikal Malaysia Mela$\mathrm{ka}$.

Mohd Effendi Ewan, M. M. (2019b). The Impact of EQ, SQ and IQ towards AQ Using 
Path Analysis and Rasch Logit for Modelling Purpose among Mechanical Engineering Students. In Proceedings of the Mechanical Engineering Research Day (pp. 225-256). Melaka: Universiti Teknikal Malaysia Melaka.

Mohd Effendi Ewan, M. M., \& Ahmad Zamri, K. (2016). Correlation between Adversity Quotient (AQ) with IQ, EQ and SQ among Polytechnic Students Using Rasch Model. Indian Journal of Science and Technology, 9, 1-8. https://doi.org/10.17485/ijst/2015/v8i1/108695

Mohd Effendi Ewan, M. M., Ahmad Zamri, K., Nordin, A. R., \& Maslawati, M. (2017). Improving the Psychometric Properties of the Mooney Problem Checklist by Using Rasch Measurement Model. Journal of Fundamental and Applied Sciences, 9, 408-428. https://doi.org/10.1016/S0040-1951(06)00452-5

Ojo, B. Y., \& Raja Nerina, R. Y. (2013). Edutourism: International Student's Decision Making Process in Selecting a Host University in Malaysia. European Journal of Business and Management, 5, 51-57.

Padlee, S. F., Kamaruddin, A. R., \& Baharun, R. (2010). International Students' Choice Behaviour for Higher Education at Malaysian Private Universities. International Journal of Marketing Studies, 2, 202-211. https://doi.org/10.5539/ijms.v2n2p202

Paulsen, M. B. (2001). The Economics of Human Capital and Investment in Higher Education. In M. B. Paulsen, \& J. C. Smart (Eds.), The Finance of Higher Education: Theory, Research, Policy and Practice (pp. 55-94). New York: Agathon Press.

Sewell, W. H., Hauser, R. M., \& Wolf, W. C. (1986). Sex, Schooling and Occupational Status. American Journal of Sociology, 86, 551-583. https://doi.org/10.1086/227281

Wilkins, S., \& Epps, A. (2011). Student Evaluation Web Sites as Potential Sources of Consumer Information in the United Arab Emirates. International Journal of Educational Management, 25, 410-422. https://doi.org/10.1108/09513541111146341 